\title{
Surface characterization, hemo- and cytocompatibility of segmented poly(dimethylsiloxane)-based polyurethanes
}

\author{
Marija V. Pergal ${ }^{1}$, Jelena Nestorov ${ }^{2}$, Gordana Tovilović-Kovačević ${ }^{2}$, Petar Jovančić ${ }^{3}$, Lato Pezo ${ }^{4}$, \\ Dana Vasiljević-Radović ${ }^{1}$, Jasna Djonlagic ${ }^{3}$ \\ ${ }^{1}$ Institute of Chemistry, Technology and Metallurgy, University of Belgrade, Belgrade, Serbia \\ ${ }^{2}$ Department of Biochemistry, Institute for Biological Research "Siniša Stanković", University of Belgrade, Belgrade, \\ Serbia \\ ${ }^{3}$ Faculty of Technology and Metallurgy, University of Belgrade, Belgrade, Serbia \\ ${ }^{4}$ Institute of General and Physical Chemistry, University of Belgrade, Belgrade, Serbia
}

\begin{abstract}
Segmented polyurethanes based on poly(dimethylsiloxane), currently used for biomedical applications, have sub-optimal biocompatibility which reduces their efficacy. Improving the endothelial cell attachment and blood-contacting properties of PDMS-based copolymers would substantially improve their clinical applications. We have studied the surface properties and in vitro biocompatibility of two series of segmented poly(urethane-dimethylsiloxane)s (SPU-PDMS) based on hydroxypropyl- and hydroxyethoxypropyl-terminated PDMS with potential applications in blood-contacting medical devices. SPU-PDMS copolymers were characterized by contact angle measurements, surface free energy determination (calculated using the van Oss-Chaudhury-Good and Owens-Wendt methods), and atomic force microscopy. The biocompatibility of copolymers was evaluated using an endothelial EA.hy926 cell line by direct contact assay, before and after pre-treatment of copolymers with multicomponent protein mixture, as well as by a competitive blood-protein adsorption assay. The obtained results suggested good blood compatibility of synthesized copolymers. All copolymers exhibited good resistance to fibrinogen adsorption and all favored albumin adsorption. Copolymers based on hydroxyethoxypropyl-PDMS had lower hydrophobicity, higher surface free energy and better microphase separation in comparison with hydroxypropyl-PDMS-based copolymers, which promoted better endothelial cell attachment and growth on the surface of these polymers as compared to hydroxypropyl-PDMS-based copolymers. The results showed that SPU-PDMS copolymers display good surface properties, depending on the type of soft PDMS segments, which can be tailored for biomedical application requirements such as biomedical devices for short- and long-term uses.
\end{abstract}

Keywords: polyurethanes, siloxanes, surface free energy, cell adhesion, protein adsorption.
Polymers

\section{SCIENTIFIC PAPER}

UDC 678.13:678.664:544

Hem. Ind. 68 (6) 731-741 (2014)

doi: 10.2298/HEMIND141103082P

Available online at the Journal website: http://www.ache.org.rs/HI/

Thermoplastic segmented polyurethane elastomers (SPUs) are used extensively in cardiovascular devices such as heart valves and vein replacements, as an encapsulating material, for orthopedic and dermal application, and for transdermal drug delivery patches [1]. They possess relatively good biocompatibility, are easy to process, and have a wide range of tunable physical and mechanical properties [1,2]. The SPUs are known to exhibit a two-phase microstructure due to the thermodynamic incompatibility between the hard and soft segments.

In the last 10 years, the poly(dimethylsiloxane) (PDMS) has often been used to produce SPUs due to

Correspondence: M.V. Pergal, Institute of Chemistry, Technology and Metallurgy - Center of Chemistry, University of Belgrade, Njegoševa 12, 11000 Belgrade, Serbia.

E-mail: marijav@chem.bg.ac.rs

Paper received: 3 November, 2014

Paper accepted: 13 November, 2014 the fact that PDMS exhibits excellent thermal properties, hydrophobic properties and biostability $[1,3,4]$. PDMS is the non-polar oligomer, which hampers its conjunction with polar urethane matrix [5]. To overcome the difficulties, many approaches have been studied in order to synthesize the PDMS-based SPUs yielding high molecular weight and good mechanical properties. In line with these, the synthesis of high molecular weight SPU copolymers using hydroxybutyl-, hydroxyhexyl-, aminopropyl- and methylaminopropylterminated PDMS oligomers has been reported [6,7]. However, most of the research was focused on using hydroxyl-terminated PDMS or amino-terminated PDMS by cooperating with polyether macrodiol, in order to increase the compatibility of the reaction mixture and, thus, to achieve higher molecular weights and better mechanical properties of copolymers [7]. For instance, Adhikari et al. [8] studied the ability of hydroxyethoxypropyl terminated-PDMS to mix with the poly(hexa- 
methylene oxide) macrodiol (PHMO) as the soft segment of the SPUs, and the results indicated that about 20 wt.\% PHMO in the soft segment produced SPUs with a combination of good biostability and mechanical properties. However, to further enhance the biostability of SPUs derived from hydroxyethoxypropyl terminated-PDMS, reduction of PHMO in the soft segment mixture is desirable [9-11].

Introduction of PDMS soft segment or siloxane based chain extenders into polyurethanes has led to the development of materials such as commercial polyether/PDMS based SPUs, i.e., Elast-Eon ${ }^{\mathrm{TM}} 2$ and 3, which comprise groups of very flexible high and low modulus SPU copolymers, respectively [1]. PDMS has been incorporated into these copolymers in order to obtain non-cytotoxic polymers with better microphase separation structures, and thus enhanced biostability and low thrombogenicity $[11,12]$. However, SPUs and PDMS in Elast-Eon ${ }^{\mathrm{TM}}$ are inherently resistant to cell adhesion and support relatively poor endothelial cell growth. Bax et al. [12] found that Elast-Eon ${ }^{\mathrm{TM}}$ exhibits low levels of human umbilical vein endothelial cell (HUVEC) adhesion and cell viability, but surface plasma modification and tropoelastin protein coating of Elast-Eon $^{\mathrm{TM}}$ enhanced endothelial cell attachment and reduced thrombogenicity.

SPUs possess blood-contacting properties that make them suitable for short and long-term biomedical applications, however their long-term thrombogenic nature can cause emboli occlusion [1]. Thrombosis is the major cause of short-term failure of heart valves, stents and vascular grafts. The investigation of protein adsorption, which is the first step in thrombus formation, is very important for understanding the molecular mechanisms underlying this process, and more importantly for engineering thromboresistant surfaces. Also, the structural conformation of the adsorbed protein appears to be crucial in influencing cell adhesion and growth [13], and studies on the behavior of protein adsorption and cell adhesion are important for improving the biocompatibility of SPU materials. In vitro cell culture in controlled conditions is one of the most often-used methods for evaluation of cytocompatibility, while the blood-based testing and plasma protein adsorption assays provide a good insight into the hemocompatible properties of the material [1]. The properties of SPUs surfaces are utmost important due to their role in thrombosis and inflammatory response. Namely, surface properties such as topography, surface free energy, surface composition, and chemistry of SPUs can greatly influence its protein adsorption, cell attachment and hence its biocompatibility [14-18]. In our previous works [16-18], we have found that microphase separation, surface roughness and soft segment content represent the most important properties inf- luencing endothelial cell adhesion and protein adsorption.

The present work is focused on the surface properties, in vitro hemo- and cytocompatibility of two series of poly(urethane-dimethylsiloxane) copolymers (SPU-PDMS) based on hydroxypropyl- and hydroxyethoxypropyl-terminated PDMS. Therefore, the aim of this study is to investigate the influence of different soft PDMS segments on the water contact angle, surface free energy and its components, surface topography and biocompatibility of SPU-PDMS copolymers.

\section{EXPERIMENTAL PART}

\section{Materials}

$\alpha, \omega$-Dihydroxypropyl poly(dimethylsiloxane) (HPPDMS, $M_{\mathrm{n}}=960 \mathrm{~g} / \mathrm{mol}$ ) and $\alpha, \omega$-dihydroxyethoxypropyl poly(dimethylsiloxane) (EO-PDMS, $M_{\mathrm{n}}=1000$ $\mathrm{g} / \mathrm{mol}$ ) were purchased from ABCR. 4,4'-Methylenediphenyldiisocyanate (MDI), supplied by Aldrich, with an isocyanate content of 33.6 wt.\%, was used without further purification. 1,4-Butanediol (BD, from Aldrich) used as a chain extender was purified by vacuum distillation. Stannous octanoate $\left(\mathrm{Sn}(\mathrm{Oct})_{2}\right)$ from Aldrich was used as a dilute solution in the anhydrous mixture of DMAc/THF $(1 / 1, \quad V / V)$. N,N-Dimethylacetamide (DMAc, from Acros) and tetrahydrofuran (THF, from J.T. Baker) were distilled before use. Formamide (analytically pure, Merck) and diiodomethane (analytically pure, UCB, Belgium) were used as received.

\section{Synthesis of segmented polyurethanes}

Two series of segmented polyurethanes were obtained by two-stage polymerization procedure in the solution (DMAC/THF, $1 / 1, V / V$ ), using $\alpha, \omega$-dihydroxypropyl- or $\alpha, \omega$-dihydroxyethoxypropyl-PDMS, MDI and $\mathrm{BD}$. Each series of the synthesized SPU-PDMS consisted of three samples of different hard segment content $(20,45$ and 55 wt.\%), which, in this study, is marked by the last two numbers in the name of prepared samples. The total molar ratio of $-\mathrm{NCO}$ and $-\mathrm{OH}$ groups was kept constant $(\mathrm{NCO} / \mathrm{OH}=1.05)$. Catalyst concentration was kept at $0.04 \mathrm{wt} . \%$. The synthesis and characterization of SPU-PDMS copolymers have been described in details in our previously published papers $[17,19]$. SPU-PDMS samples were synthesized in $100 \mathrm{~mL}$ four-neck roundbottom flasks, placed in a silicone oil bath and connected to an inlet for dry argon, a mechanical stirrer, a dropping funnel and a reflux condenser. Calculated amounts of macrodiol and MDI were weighed into reaction flask at room temperature, dissolved in the mixture of DMAc/THF and then heated up to 80 (for the SPU-PDMS $S_{H P}$ series) or $40{ }^{\circ} \mathrm{C}$ (for the SPU-PDMS series) under an argon atmosphere. The reaction started by the introduction of a solution of $\mathrm{Sn}(\mathrm{Oct})_{2}$ in 
DMAc/THF. The reaction mixture was stirred for $20 \mathrm{~min}$ (for the SPU-PDMS $\mathrm{HP}_{\mathrm{HP}}$ series) or $30 \mathrm{~min}$ (for the SPU- PDMS $_{\text {EO }}$ series) to prepare the NCO-terminated prepolymer, i.e., until the theoretical NCO content was attained. The NCO content was controlled by the dibutylamine back-titration method [20]. In the second stage of the reaction, a dilute solution of $B D$ in DMAc/THF was added dropwise to the NCO-terminated prepolymer and the reaction was continued for $24 \mathrm{~h}$. Copolymers were precipitated into methanol/water $(1 / 1, V / V)$ solution, filtered and dried to constant weight in a vacuum oven at $40{ }^{\circ} \mathrm{C}$. The SPU-PDMS films (0.40-0.50 $\mathrm{mm}$ thickness) utilized for characterization and biocompatibility evaluation were cast from DMAc solution (10 wt.\%) into Teflon ${ }^{\circledR}$ molds and were left for $48 \mathrm{~h}$ in a circulating air oven at $40{ }^{\circ} \mathrm{C}$. Finally, the films were dried to constant weight under vacuum at $40^{\circ} \mathrm{C}$.

\section{Characterization}

Static contact angle was measured by a sessile drop method at $26^{\circ} \mathrm{C}$, using a contact angle analyzer (Krüss DSA100). Surface energy data were calculated from the contact angle values obtained by distilled water, formamide, and diiodomethane and the acid-base theory for solids according to the van Oss-Chaudhury-Good model [21]. Also, surface free energy and its components were obtained using the water and diiodomethane contact angles according to the Owens-Wendt model [22]. Single drops of tested liquid with a volume of $20 \mu \mathrm{L}$ were deposited on the film surface and the contact angels were measured after $30 \mathrm{~s}$. Contact angles for each polymer were calculated as the average value of five measurements.

The surface free energy can be calculated by the acid-base theory for solids according to the van Oss-Chaudhury-Good approach using the following equations [21]:

$$
\begin{aligned}
& \gamma_{L V 1}\left(1+\cos \theta_{1}\right)=2 \sqrt{\gamma_{S}^{L W} \gamma_{L V 1}^{L W}}+\sqrt{\gamma_{S}^{+} \gamma_{L V 1}^{-}}+\sqrt{\gamma_{S}^{-} \gamma_{L V 1}^{+}} \\
& \gamma_{L V 2}\left(1+\cos \theta_{2}\right)=2 \sqrt{\gamma_{S}^{L W} \gamma_{L V 2}^{L W}}+\sqrt{\gamma_{S}^{+} \gamma_{L V 2}^{-}}+\sqrt{\gamma_{S}^{-} \gamma_{L V 2}^{+}} \\
& \gamma_{L V 3}\left(1+\cos \theta_{3}\right)=2 \sqrt{\gamma_{S}^{L W} \gamma_{L V 3}^{L W}}+\sqrt{\gamma_{S}^{+} \gamma_{L V 3}^{-}}+\sqrt{\gamma_{S}^{-} \gamma_{L V 3}^{+}} \\
& \gamma_{S}=\gamma_{S}^{L W}+\gamma_{S}^{A B}=\gamma_{S}^{L W}+2 \sqrt{\gamma_{S}^{+} \gamma_{S}^{-}}
\end{aligned}
$$

where $\theta$ is the experimentally found contact angle between a liquid drop and a solid surface under investigation; $\gamma_{s}$ is the total surface free energy of copolymers and composed of the dispersive $\left(\gamma_{S}^{\perp W}\right)$ and the polar $\left(\gamma_{S}^{A B}\right)$ components; $\dot{\gamma}^{+}$and $\bar{\gamma}$ are the Lewis acid parameter and the Lewis base parameter of the surface free energy, respectively; $\gamma_{L V}$ represents the surface tension of the corresponding testing liquids, and it is also divided into the dispersive and the polar components. In this way, if the values of $\gamma_{L V}^{L W}, \gamma_{L V}^{+}, \gamma_{L V}^{-}$ for three testing liquids are known, $\gamma_{S}^{\perp W}$ and $\gamma_{S}^{A B}$ can be calculated according to Eq. (1) by measuring contact angles $\theta_{1}, \theta_{2}$ and $\theta_{3}$ of three testing liquids on the SPU-PDMS surface, which can further give the surface free energy of solid film. Here the three testing liquids are distilled water $\left(\gamma_{L V}=72.8 \mathrm{~mJ} / \mathrm{m}^{2} ; \gamma_{L V}^{L W}=21.8 \mathrm{~mJ} / \mathrm{m}^{2}\right.$; $\left.\gamma_{L V}^{+}=25.5 \mathrm{~mJ} / \mathrm{m}^{2} ; \gamma_{L V}^{-}=25.5 \mathrm{~mJ} / \mathrm{m}^{2}\right)$, formamide $\left(\gamma_{L V}=\right.$ $58.0 \mathrm{~mJ} / \mathrm{m}^{2} ; \gamma_{L V}^{L W}=39.0 \mathrm{~mJ} / \mathrm{m}^{2} ; \gamma_{L V}^{+}=2.28 \mathrm{~mJ} / \mathrm{m}^{2} ; \gamma_{L V}^{-}$ $\left.=39.6 \mathrm{~mJ} / \mathrm{m}^{2}\right)$, and diiodomethane $\left(\gamma_{L V}=50.8 \mathrm{~mJ} / \mathrm{m}^{2}\right.$; $\left.\gamma_{L V}^{L W}=50.8 \mathrm{~mJ} / \mathrm{m}^{2} ; \gamma_{L V}^{+}=0 \mathrm{~mJ} / \mathrm{m}^{2} ; \gamma_{L V}^{-}=0 \mathrm{~mJ} / \mathrm{m}^{2}\right)[23]$.

The surface free energy can be calculated according to the Owens-Wendt model using the following equations [22]:

$$
\begin{aligned}
& \gamma_{L V 1}\left(1+\cos \theta_{1}\right)=2 \sqrt{\gamma_{S}^{d} \gamma_{L V 1}^{d}}+\sqrt{\gamma_{S}^{p} \gamma_{L V 1}^{p}} \\
& \gamma_{L V 3}\left(1+\cos \theta_{3}\right)=2 \sqrt{\gamma_{S}^{d} \gamma_{L V 3}^{d}}+\sqrt{\gamma_{S}^{p} \gamma_{L V 3}^{p}} \\
& \gamma_{S}=\gamma_{S}^{d}+\gamma_{S}^{p}
\end{aligned}
$$

where $\gamma_{S}^{d}$ is the surface free energy connected with dispersion interactions; $\gamma_{s}^{p}$ is the surface free energy connected with polar interactions.

Atomic force microscopy (AFM) characterizations were performed with an AutoProbe CP-Research SPM (TM Microscopes, Veeco) instrument. Measurements were performed under ambient conditions using the non-contact mode AFM technique. Veeco Phosphorus (n)-doped silicon contact metrology probes model MPP-31123-10 with Al-reflective coating and symmetric tip were used.

Differential scanning calorimetry (DSC) was carried out on a DSC Q1000V9.0 Build 275 thermal analyzer. The DSC scans were recorded under a dynamic nitrogen atmosphere (the flow rate of nitrogen was 50 $\mathrm{mL} / \mathrm{min}$ ), in the temperature range from -90 to $230{ }^{\circ} \mathrm{C}$, at a heating and cooling rate of 10 and $5{ }^{\circ} \mathrm{C} / \mathrm{min}$, respectively. The total degree of crystallinity $\left(X_{\mathrm{CDSC}}\right)$ was calculated by following equation:

$X_{\mathrm{cDSC}}=\Delta H_{\mathrm{m}} / \Delta H_{\mathrm{m}}{ }^{\circ}$

where $\Delta H_{\mathrm{m}}$ is the enthalpy of melting of sample, and $\Delta H_{m}{ }^{\circ}$ is the theoretical value of the enthalpy of the melting of perfectly crystalline MDI-BD homopolymer, based on the group contribution method $\left(\Delta H_{\mathrm{m}}{ }^{\circ}=91.2\right.$ $\mathrm{J} / \mathrm{g}$ ) [24].

\section{Assessment of cytocompatibility}

EA.hy926 cells were a kind gift from Dr. Cora Jean Edgell, University of North Carolina, USA. The cells were cultured in Dulbecco's Modified Eagle Media supplemented with $10 \%$ fetal bovine serum, $2 \mathrm{mM}$ L-glutamine, $100 \mathrm{\mu g} / \mathrm{cm}^{3}$ streptomycin, $100 \mathrm{U} / \mathrm{cm}^{3}$ penicillin, and HAT media supplement and maintained in a humidified atmosphere containing $5 \% \mathrm{CO}_{2}$ at $37{ }^{\circ} \mathrm{C}$. Prior to cell seeding, SPU-PDMS copolymers films were sterilized by ultraviolet irradiation for $30 \mathrm{~min}$ and placed into 96 well polystyrene microplates (Sarstedt, Ger- 
many). The cells were seeded at a density of 30000 cells per well for all experiments. All tests were performed in triplicates.

The influence of SPU-PDMS copolymers on cell viability was evaluated using (MTT) assay, which was performed 96 hours post-seeding [16]. Absorbance was measured spectrophotometrically at $570 \mathrm{~nm}$. The cell viability was expressed relative to control sample (cells grown without sample film), taken as $100 \%$.

Cell adhesion onto the SPU-PDMS copolymers films was examined and photographed by a light microscopy using a computer based Carl Zeiss Axiovision microscope, $96 \mathrm{~h}$ after seeding. Cells were fixated with $3 \%$ glutaraldehyde solution. The samples were rinsed with PBS in order to remove detached cells. SPU-PDMS copolymers films were placed on microscope slides, stained with $0.4 \%$ nigrosin solution and photographed.

To assess the possible influence of surface preconditioning with the most abundant plasma proteins on cell adhesion, the samples were pre-incubated for $2 \mathrm{~h}$ at $37{ }^{\circ} \mathrm{C}$ in the mixture of bovine serum albumin (BSA, $40 \mathrm{mg} / \mathrm{cm}^{3}$ ), bovine $\gamma$ globulins (BGG, $10 \mathrm{mg} / \mathrm{cm}^{3}$ ) and bovine fibrinogen (FBG, $3 \mathrm{mg} / \mathrm{cm}^{3}$ ) prior to cell seeding. Protein concentrations are chosen as to reflect the actual physiological concentration. After incubation, the SPU-PDMS films were rinsed two times with PBS. The cells were seeded in specified density of 30000 cells per well and SPU-PDMS copolymers films were photographed 96 hours after as indicated above.

\section{Assessment of hemocompatibility}

SPU-PDMS copolymer films were incubated ( $2 \mathrm{~h}, 37$ ${ }^{\circ} \mathrm{C}$ ) with a three-component mixture comprised of BSA $\left(40 \mathrm{mg} / \mathrm{cm}^{3}\right)$, BGG $\left(10 \mathrm{mg} / \mathrm{cm}^{3}\right)$ and FBG $\left(3 \mathrm{mg} / \mathrm{cm}^{3}\right)$. Adsorbed proteins were resolved on $7.5 \%$ SDS-poly(acrylamide) gels under non-reducing conditions and quantified as previously reported [16]. The protein concentrations were calculated from the standard curves and expressed as $\mu$ g of protein per $\mathrm{cm}^{2}$ of the film.

\section{Statistical analysis}

Biocompatibility data were evaluated statistically by one way ANOVA, followed by post comparison Bonferroni's test: * indicates $p<0.05 ;{ }^{* *} p<0.01 ; * * *$ $p<0.001$. For surface free energy data, descriptive statistical analyses for calculating the means and the standard error of the mean were performed using Microsoft Excel software (Microsoft Office 2007). All obtained results were expressed as the mean \pm standard deviation (SD). The significant differences between specific samples are calculated according to post-hoc Tukey's HSD test at $p<0.05$ significance level, $95 \%$ confidence limit, using StatSoft Statistica 10 software.

\section{RESULTS AND DISCUSSION}

Two series of SPU-PDMS copolymers containing different soft segment structures were synthesized by two-step polymerization in solution. These SPU-PDMS copolymers were used to study the effect of surface properties on hemo- and cytocompatibility. The chemical structure of two kinds of PDMS prepolymer used for preparation of SPU-PDMS copolymers are presented in Figure 1. The molar ratio of PDMS, MDI and $\mathrm{BD}$ in both series was 1:2:1, 1:4:3 and 1:6:5, which resulted in following of predetermined content of the hard MDI-BD segments: 20, 45 and 55 wt.\%. The compositions and some DSC data of the examined copolymers are given in Table 1.

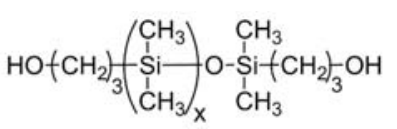

$\alpha, \omega$-dihydroxypropyl poly(dimethylsiloxane)

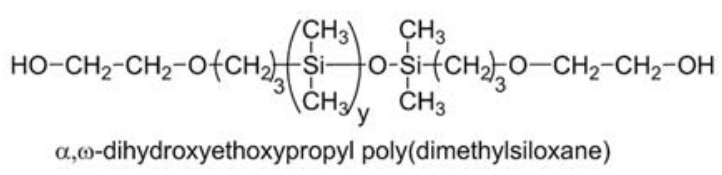

Figure 1. Chemical structures of poly(dimethylsiloxane) prepolymers.

\begin{tabular}{|c|c|c|c|c|c|c|}
\hline Sample & Molar ratio ${ }^{a}$ & $\begin{array}{l}\text { Content of hard segment, wt.\% } \\
\text { (in feed) }\end{array}$ & $X_{\mathrm{CDSC}} / \%^{\mathrm{c}}$ & $\begin{array}{c}\theta_{1} /^{\mathrm{o}} \\
\text { (water) }^{\mathrm{d}}\end{array}$ & $\begin{array}{c}\theta_{2} /^{\mathrm{o}} \\
\text { (formamide) }^{\mathrm{d}}\end{array}$ & $\begin{array}{c}\theta_{3} /^{\circ} \\
\text { (diiodomethane) }^{\mathrm{d}}\end{array}$ \\
\hline SPU-PDMS $_{\mathrm{HP}}-20$ & 1:2:1 & 21.9 & 0.9 & $96.2 \pm 1.2^{\mathrm{e}}$ & $84.3 \pm 2.6^{d}$ & $71.4 \pm 1.2^{\mathrm{e}}$ \\
\hline $\mathrm{SPU} \mathrm{PDMS}_{\mathrm{HP}}-45$ & $1: 4: 3$ & 45.7 & 18.9 & $88.5 \pm 0.9^{a}$ & $78.4 \pm 1.2^{b}$ & $66.0 \pm 0.7^{d}$ \\
\hline SPU-PDMS $_{\mathrm{HP}}-55$ & $1: 6: 5$ & 58.4 & 27.2 & $83.3 \pm 1.0^{c}$ & $70.5 \pm 0.4^{a}$ & $56.8 \pm 0.4^{c}$ \\
\hline SPU-PDMS $\mathrm{EO}_{\mathrm{EO}}-20$ & $1: 2: 1$ & 21.4 & 4.3 & $92.7 \pm 0.4^{d}$ & $77.8 \pm 1.2^{b}$ & $62.4 \pm 1.2^{\mathrm{a}}$ \\
\hline SPU-PDMS $\mathrm{EO}-45$ & $1: 4: 3$ & 44.9 & 19.6 & $87.0 \pm 0.4^{\mathrm{a}}$ & $71.6 \pm 1.5^{a}$ & $59.9 \pm 0.4^{a}$ \\
\hline SPU-PDMS ${ }_{\mathrm{EO}}-55$ & $1: 6: 5$ & 57.6 & 28.5 & $80.8 \pm 0.6^{b}$ & $63.5 \pm 1.9^{c}$ & $43.5 \pm 1.4^{b}$ \\
\hline
\end{tabular}

Table 1. Composition, degree of crystallinity and contact angles of the SPU-PDMS copolymers

${ }^{a}$ PDMS prepolymer:MDI:BD in the reaction mixture; at a 1.05 mole ratio of $\mathrm{NCO} / \mathrm{OH}$ groups; ${ }^{b}$ predetermined by the composition of the reaction mixtures; ${ }^{c}$ determined by DSC results from the second heating run. The degree of crystallinity of SPU-PDMS $\mathrm{HP}_{\mathrm{HP}}-20$ sample is $2.6 \%$ in the first heating run; ${ }^{d} a, b, c, d, e-$ values with the same letter are not statistically different at the $p<0.05$ level (according to post-hoc Tukey's HSD test) 
Since the synthesized SPU-PDMS copolymers prepared from the soft PDMS and hard MDI-BD segments were designed to obtain materials for biomedical applications, their surface energy and hydrophobicity/hydrophilicity play a key role. In the present study, the surface free energy of SPU-PDMS copolymers was calculated according to the van Oss-Chaudhury-Good [21] and Owens-Wendt methods [22]. In order to find and to validate the values of surface free energy those two methods were applied. Post-hoc Tukey's HSD test at $95 \%$ confidence limit was calculated to show any significant differences between samples. Moreover, in van Oss-Chaudhury-Good or Owens-Wendt methods, three (distilled water, formamide and diiodomethane) or two (distilled water and diiodomethane) liquids for the SPU-PDMS surface investigation were used.

The measurement of the contact angle represents well-known and very useful technique for characterization of solid surface. Tables 1 and 2 show the contact angles of the SPU-PDMS copolymers by using the three liquids as well as surface free energy and its components, respectively. The contact angles of SPU- PDMS $_{\mathrm{HP}}$ and SPU-PDMS $\mathrm{EO}_{\mathrm{E}}$ samples with water $\left(\theta_{1}\right)$ increased from 83.3 to $96.2^{\circ}$ and from 80.8 to $92.7^{\circ}$, respectively, with increasing content of PDMS in the samples. In both series, the copolymers with higher PDMS content were more hydrophobic. These results may be explained by the migration tendency of PDMS on the surface of the copolymers, caused by very low surface energy of PDMS [4]. The hydrophobicity for SPU-PDMS copolymers based on HP-PDMS prepolymer is higher in comparison with copolymers based on EO-PDMS prepolymer with terminal hydrophilic ethylene oxide units. Furthermore, the values of the formamide $\left(\theta_{2}\right)$ and diiodomethane $\left(\theta_{3}\right)$ contact angle are higher for the samples of SPU-PDMS $S_{H P}$ series in comparison with the samples of SPU-PDMS ${ }_{E O}$ series. As shown in Table 2, the surface free energy of copolymers based on HP-PDMS is lower than that of copolymers based on EO-PDMS. Surface free energy of SPU-PDMS $\mathrm{HP}_{\mathrm{HP}}$ copolymers decreased due to the higher surface activity of HP-PDMS prepolymer incorporated into the soft segment in comparison with EO-PDMS prepolymer con- taining terminal hydrophilic ethylene oxide units. It was found that the decrease in the surface energy for SPU$-\mathrm{PDMS}_{\mathrm{HP}}$ samples in comparison with SPU-PDMS $\mathrm{EO}_{\mathrm{E}}$ samples could be mainly attributed to decreasing values of the dispersive component $\gamma_{S}^{L W}$ or $\gamma_{S}^{d}$. There was a very small change in the polar component $\gamma_{S}^{A B}$ or $\gamma_{S}^{p}$ with changing type of PDMS prepolymer. The surface energy values of the synthesized SPU-PDMS samples were higher than values obtained for the other poly(urethane-siloxane)s (around $20 \mathrm{~mJ} / \mathrm{m}^{2}$ ) $[25,26]$ and silicone control sample $\left(18 \mathrm{~mJ} / \mathrm{m}^{2}\right)$ [26] presented in the literature. The results of the current study showed that the synthesized copolymers possess slightly amphiphilic character, implying the existence of both, hydrophobic PDMS and hydrophilic urethane groups at the surface.

AFM Analysis was carried out in order to understand the influence of the type of PDMS soft segments on the surface topography and heterogeneity relief of SPU-PDMS copolymers. The height and phase AFM images for SPU-PDMS copolymers are shown in Figure 2. Based on prior studies, it is known that the bright regions represent the hard phase, while the darker regions represent the soft PDMS phase. Height images show different surface topography for the synthesized copolymers. The topographies of SPU-PDMS ${ }_{\mathrm{HP}}-20, \mathrm{SPU}-$ $-\mathrm{PDMS}_{\mathrm{EO}}-20$ and SPU-PDMS $\mathrm{EO}_{-45}$ samples display spherullite particulate formations of tens of $\mathrm{nm}$ in size, SPU$-\mathrm{PDMS}_{\mathrm{HP}}-45$, SPU-PDMS $\mathrm{HP}_{\mathrm{H}}-55$, SPU-PDMS $\mathrm{EO}_{\mathrm{O}}-55$ show agglomerates of $\mu \mathrm{m}$ in size. Phase images (i.e., maps of tip-sample interactions) enable qualitative insight into the homogeneity relief of samples. The synthesized copolymers based on EO-PDMS are characterized by two-phase morphology consisting of a hard segmentrich phase and a soft segment-rich phase. Therefore, the EO-PDMS based copolymers are distinguished by heterogeneous character, apparently connected with the good microphase separation. On the contrary, the copolymers based on HP-PDMS do not have sharp interfaces between the two phases, i.e., they have mostly homogeneous character, apparently connected with the weak microphase separation.

Table 2. Results of surface free energy $\left(\mathrm{mJ} / \mathrm{m}^{2}\right)$, its components and parameters for the SPU-PDMS copolymers calculated according to van Oss-Chaudhury-Good and Owens-Wendt methods; values with the same letter are not statistically different at the $p<0.05$ level (according to post-hoc Tukey's HSD test)

\begin{tabular}{|c|c|c|c|c|c|c|c|c|}
\hline \multirow[t]{2}{*}{ Sample } & \multicolumn{5}{|c|}{ van Oss-Chaudhury-Good method } & \multicolumn{3}{|c|}{ Owens-Wendt method (water-diiodomethane liquids) } \\
\hline & $\gamma_{s}^{\perp W}$ & $\gamma_{S}^{+}$ & $\gamma_{s}^{-}$ & $\gamma_{S}^{A B}$ & $\gamma_{s}$ & $\gamma_{s}^{d}$ & $\gamma_{S}^{p}$ & $\gamma_{s}$ \\
\hline SPU-PDMS ${ }_{\mathrm{HP}}-20$ & $22.1 \pm 0.7^{b}$ & $1.5 \pm 0.3^{\mathrm{a}}$ & $1.9 \pm 0.4^{c}$ & $3.3 \pm 0.6^{b}$ & $25.4 \pm 1.1^{c}$ & $24.3 \pm 0.1^{a}$ & $1.2 \pm 0.0^{b}$ & $25.5 \pm 0.2^{a}$ \\
\hline SPU-PDMS ${ }_{H P}-45$ & $25.1 \pm 0.5^{c}$ & $1.6 \pm 0.2^{\mathrm{ab}}$ & $2.8 \pm 0.1^{\mathrm{ab}}$ & $4.3 \pm 0.2^{\mathrm{ac}}$ & $29.4 \pm 0.7^{\mathrm{ab}}$ & $29.8 \pm 0.1^{c}$ & $1.3 \pm 0.0^{c}$ & $31.0 \pm 0.2^{c}$ \\
\hline $\mathrm{SPU}_{\mathrm{PDMS}} \mathrm{HP}-55$ & $30.4 \pm 0.2^{d}$ & $1.8 \pm 0.1^{\mathrm{ab}}$ & $3.0 \pm 0.4^{b}$ & $4.6 \pm 0.3^{\mathrm{a}}$ & $35.0 \pm 0.3^{d}$ & $27.2 \pm 0.2^{\mathrm{b}}$ & $2.0 \pm 0.0^{\mathrm{e}}$ & $29.1 \pm 0.3^{b}$ \\
\hline SPU-PDMS $\mathrm{EO}_{-20}$ & $27.3 \pm 0.8^{\mathrm{a}}$ & $1.9 \pm 0.3^{\mathrm{ab}}$ & $1.8 \pm 0.2^{c}$ & $3.7 \pm 0.4^{b c}$ & $31.1 \pm 1.0^{\mathrm{ab}}$ & $30.5 \pm 0.3^{d}$ & $1.7 \pm 0.0^{\mathrm{a}}$ & $32.2 \pm 0.1^{d}$ \\
\hline SPU-PDMS $\mathrm{EO}-45$ & $28.6 \pm 0.3^{a}$ & $1.6 \pm 0.1^{\mathrm{a}}$ & $2.4 \pm 0.0^{\mathrm{ab}}$ & $3.9 \pm 0.2^{\mathrm{abc}}$ & $32.5 \pm 0.4^{b}$ & $33.0 \pm 0.3^{\mathrm{e}}$ & $1.7 \pm 0.0^{\mathrm{a}}$ & $34.7 \pm 0.3^{\mathrm{e}}$ \\
\hline $\mathrm{SPU} \mathrm{PDMS}_{\mathrm{EO}}-55$ & $37.4 \pm 0.7^{\mathrm{e}}$ & $2.2 \pm 0.1^{b}$ & $2.6 \pm 0.3^{\mathrm{ab}}$ & $4.8 \pm 0.4^{\mathrm{a}}$ & $42.2 \pm 0.3^{\mathrm{e}}$ & $40.8 \pm 0.2^{f}$ & $1.6 \pm 0.0^{d}$ & $42.3 \pm 0.2^{f}$ \\
\hline
\end{tabular}


a)
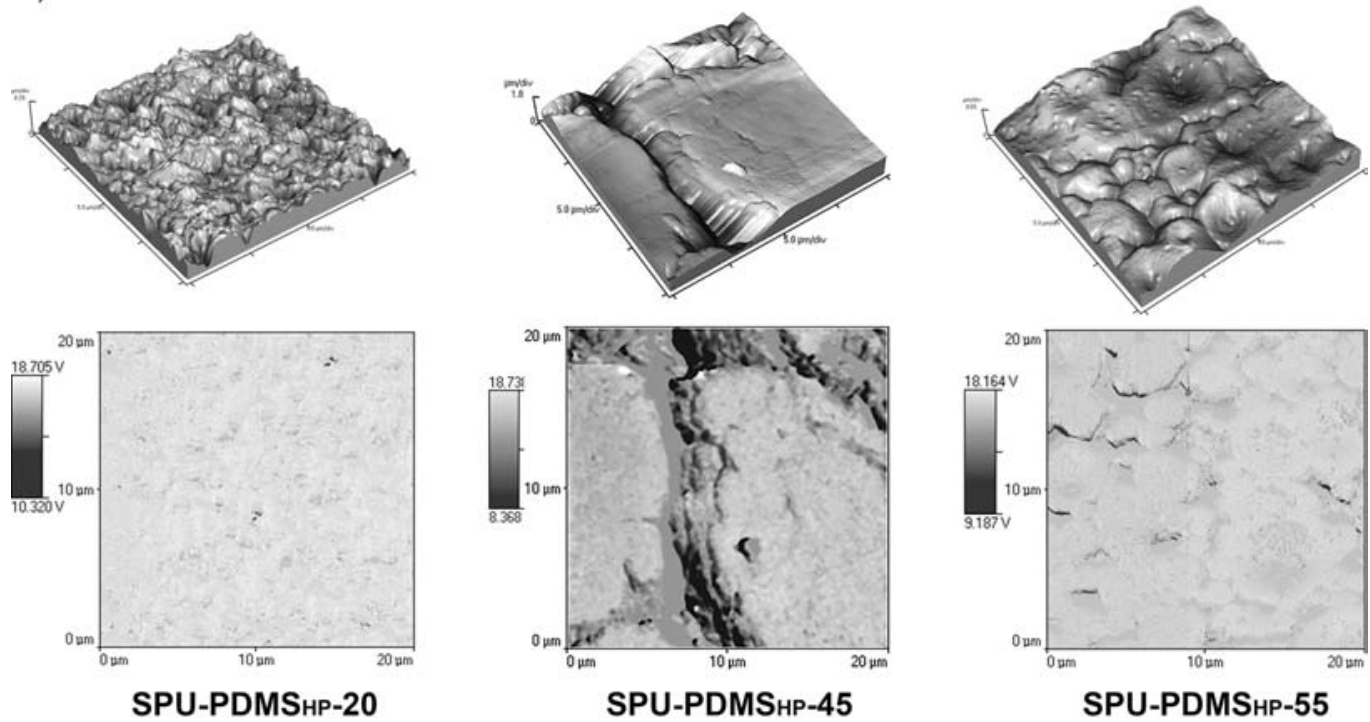

b)
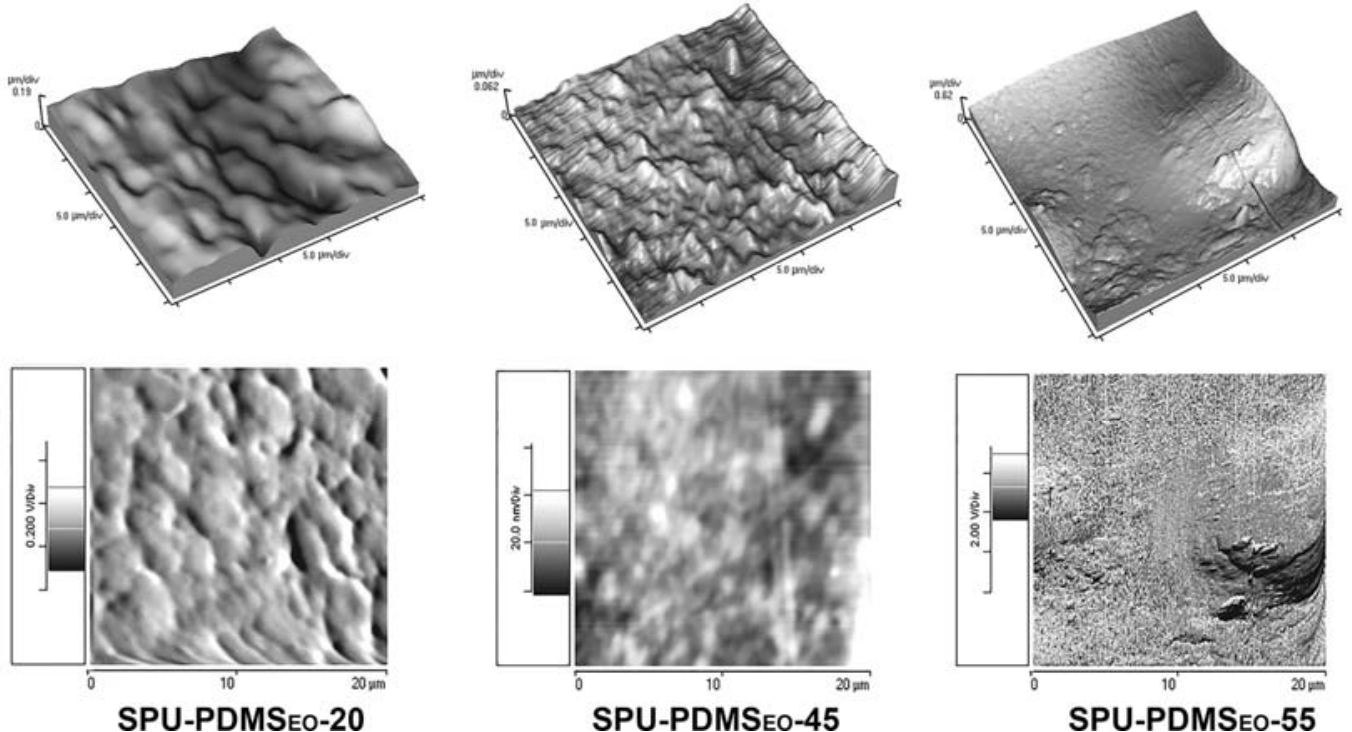

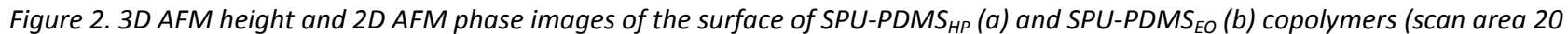
$\mu m \times 20 \mu m)$.

Investigation of biocompatibility using endothelial cells and protein adsorption assays is paramount for further development of non-toxic, thromboresistant surfaces, given that almost all currently available biomaterials (e.g., commercial PDMS/polyether based SPUs Elast-Eon ${ }^{\mathrm{TM}}$ ) have biocompatibility that is limited by inflammatory responses contributing to thrombosis formation, as well as low level of cell attachment $[1,12]$. In our study, the biocompatibility of copolymers was evaluated using endothelial EA.hy926 cell line by direct contact assay, before and after pre-treatment of copolymers with multicomponent protein mixture, as well as by a competitive blood-protein adsorption assay. Namely, in our research, we used EA.hy926 endothelial cell line to investigate cytocompatibility of the synthesized copolymers. Endothelial cells are the major cell type of the microvasculature, and they play a role in regulation of vascular tone and permeability, coagulation, inflammation and angiogenesis [1]. The response of these cells to a material is of great importance, and the endothelial cells are often used in in vitro evaluation of cytocompatibility of materials that might be used as medical devices, in particular, for the devices designed for cardiovascular applications aimed to have long-term close contacts with blood vessels.

The results of MTT assay showed that SPU-PDMS ${ }_{\mathrm{HP}}$ samples significantly inhibited attachment and growth of EA.hy926 cells, while SPU-PDMS ${ }_{E O}$ samples supported the attachment and subsequent growth of endothelial cells on their surface without restriction 
(Figure 3). The obtained results showed that the surfaces of SPU-PDMS $\mathrm{EO}_{\mathrm{EO}}$ samples might be favorable for the cell growth in comparison with the surface of SPU-PDMS ${ }_{H P}$ copolymers, probably due to the better microphase separation and greater hydrophilic properties of surfaces of EO-PDMS-based copolymers.

Cell attachment to the SPU-PDMS copolymers was investigated by light microscopy $96 \mathrm{~h}$ post seeding. The representative photographs of EA.hy 926 cells on the surface of copolymers are shown in Figure 4 . In this study, the cell attachment appeared to depend on the type of PDMS soft segments, microphase separation, as well as surface hydrophilicity. Namely, the surface of SPU-PDMS $\mathrm{EO}_{\mathrm{E}}$ samples favoured cell attachment, while a reduced cell attachment was observed in SPU-PDMS ${ }_{H P}$ samples. Consequently, cell morphology was preserved

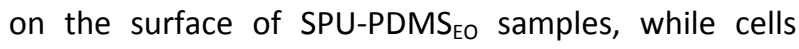
seeded onto SPU-PDMS $S_{H P}$ samples could not spread to adopt the characteristic shape. As a result, cell attachment on the SPU-PDMS $S_{E O}$ surface was much higher than on the SPU-PDMS ${ }_{\text {HP }}$ surface due to higher hydro-

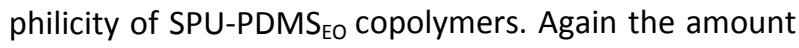
of cells attached to the SPU-PDMS $\mathrm{EO}_{\mathrm{E}}$ surface after a protein-preconditioning of their surface was much higher than on SPU-PDMS ${ }_{\mathrm{HP}}$ surface (Figure 5). Similar situation was observed after preconditioning of SPU$\mathrm{PDMS}_{\mathrm{HP}}$ and SPU-PDMS $\mathrm{EO}_{\mathrm{E}}$ copolymers surface with the three-component protein mixture (Figure 5), implying

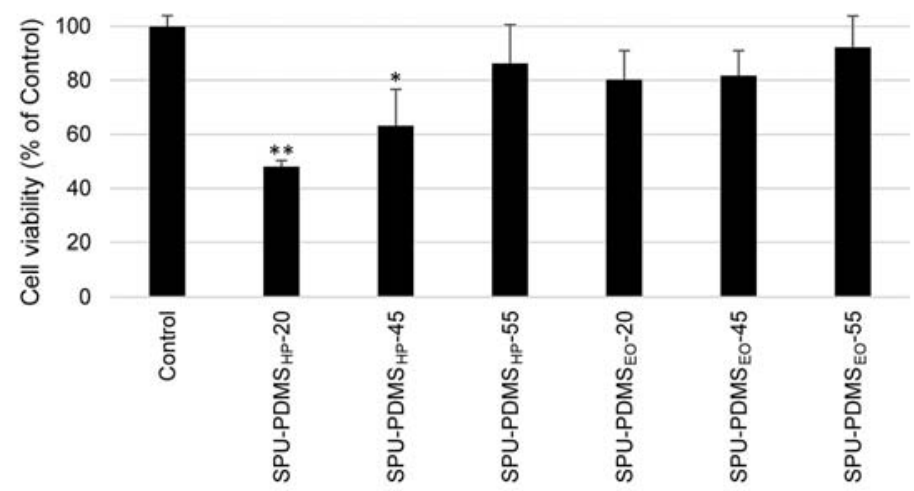

Figure 3. Ea.hy926 cell viability 96 h post seeding onto SPU-PDMS copolymers.

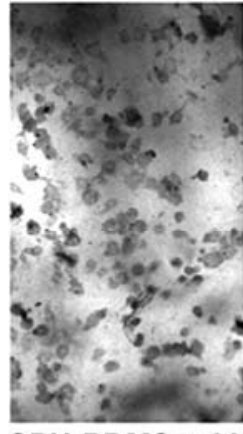

SPU-PDMS ${ }_{H P-20}$

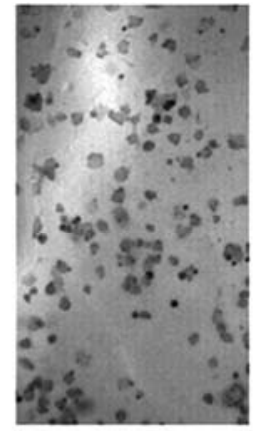

SPU-PDMS ${ }_{H P-45}$

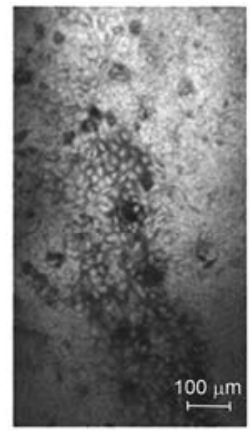

SPU-PDMS ${ }_{\mathrm{HP}-55}$

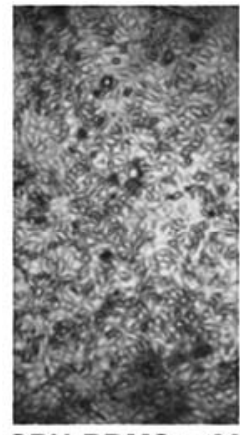

SPU-PDMS $S_{\text {EO-20 }}$

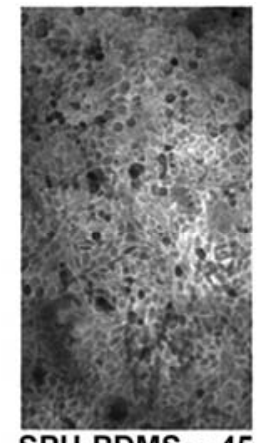

SPU-PDMS $E O-45$

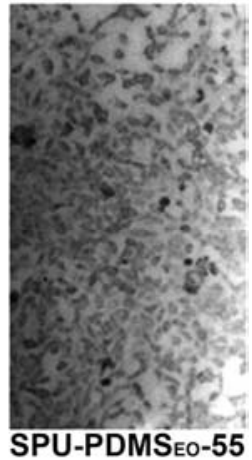

SPU-PDMS $E O-55$

Figure 4. Photographs of SPU-PDMS copolymers with EA.hy926 cells adhered on their surface.

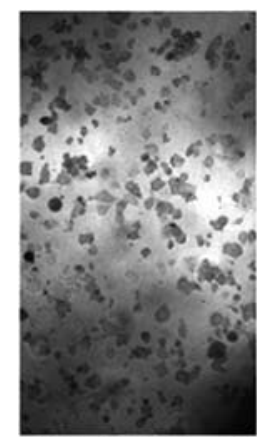

SPU-PDMS ${ }_{H P-20}$

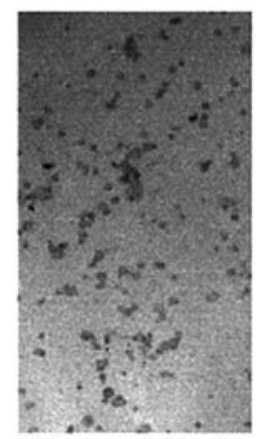

SPU-PDMS ${ }_{\mathrm{HP}-45}$

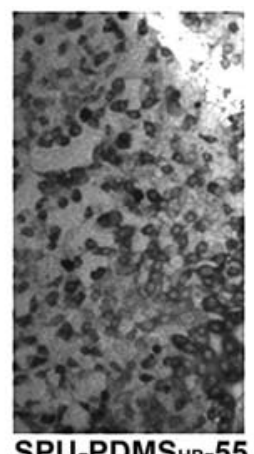

SPU-PDMS $S_{H P}-55$

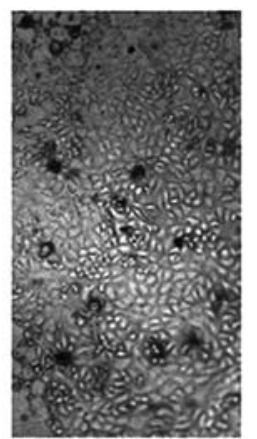

SPU-PDMSEO-20

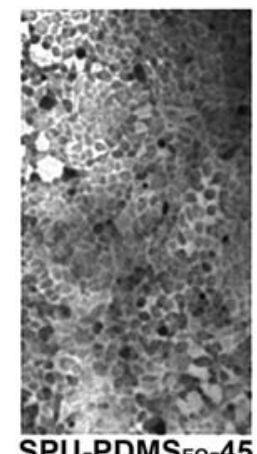

SPU-PDMS $E O-45$

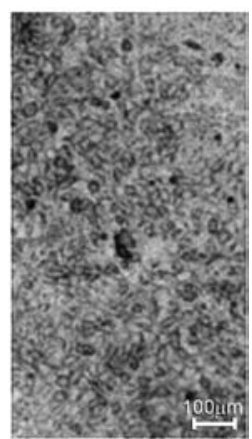

SPU-PDMS $S_{E O-55}$

Figure 5. Photographs of SPU-PDMS copolymers pre-adsorbed with proteins mixture and adhered with EA.hy926 cells. 
that pretreatment with blood proteins did not influence further cell attachment on the SPU-PDMS copolymers in both series. These results could be explained by limited FBG (i.e., cell adhesion-promoting protein) binding to all copolymers in both series. Namely, in this study the FBG/BSA adsorption ratio (Figure 6) did not affect cell attachment on the surface of proteins of pretreated copolymers. The obtained results suggested that endothelial cell attachment on the SPU-PDMS ${ }_{E O}$ copolymer surface $\left(81.4 \pm 6.0 \%\right.$ for SPU-PDMS ${ }_{E O}-20$, $81.0 \pm 9.4$ for SPU-PDMS $\mathrm{EO}-45$, and $86.4 \pm 9.9 \%$ for SPU$\left.-\mathrm{PDMS}_{\mathrm{EO}}-55\right)$ was higher than on the Elast-Eon ${ }^{\mathrm{TM}}$ (31.4 $\pm 3.8 \%)$ [12], suggesting good biocompatibility of copolymers, which were derived only from EO-PDMS as soft segment.

Our in vitro measurements of plasma protein adsorption suggested good blood compatibility of all synthesized copolymers. All copolymers exhibited good resistance to fibrinogen adsorption and all favoured albumin adsorption (Table 3). Albumin adsorption is shown to passivate and protect the biomaterial surface from thrombosis, whereas fibrinogen promotes platelet adhesion on the polymer surface [1]. The adsorption ratio of FBG/BSA for the SPU-PDMS ${ }_{\mathrm{HP}}$ and SPU-PDMS $\mathrm{EO}_{\mathrm{EO}}$ copolymers from competitive experiments was in the range from 0.0320 to 0.0501 and from 0.0092 to 0.0208 , respectively (Figure 6). The obtained results indicate that all copolymers preferentially adsorbed BSA, which is an indicator of good hemocompatibility [27]. It was suggested that polymers which show improved blood compatibility and less platelet adhesion have a smaller ratio of FBG/BSA [28], which was observed in our study. Nevertheless, in addition to blood-protein adsorption, other hemocompatibility investigations such as hemolysis and platelet adsorption, as well as in vivo testing are needed to confirm our preliminary results.

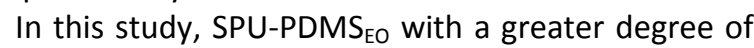
microphase separation demonstrated a lower FBG/BSA adsorption ratio in competitive experiment and therefore better hemocompatibility in comparison with SPU-
$-\mathrm{PDMS}_{\mathrm{HP}}$ copolymers. This is in agreement with previous studies on SPUs based on polyether and PDMS soft segments and SPUs based on PCL-PDMS-PCL soft segments, where higher microphase separation of samples showed lower FBG adsorption levels [16,29]. Our results also suggest that the higher surface energy may be responsible for lower FBG adsorption of SPUPDMS $_{\mathrm{EO}}$ copolymers as compared to SPU-PDMS $\mathrm{HP}_{\mathrm{P}}$ copolymers. Therefore, in this study we show that the hemocompatibility of the SPU-PDMS copolymers depends on the degree of microphase separation and surface free energy. Furthermore, the FBG interactions with SPU-PDMS ${ }_{\text {EO }}$ are similar to those with commercial polyether/PDMS based SPUs, i.e., Elast-Eon ${ }^{\mathrm{TM}}$ (adsorbed amount of FBG is $0.19 \mu \mathrm{g} / \mathrm{cm}^{2}$ in competitive adsorption experiment) [30], suggesting good biocompatibility of SPU-PDMS $\mathrm{EO}_{\mathrm{E}}$ copolymers and great promise for use in long-term blood-contacting biomaterials.

Table 3. Results of competitive adsorption of proteins on SPUPDMS copolymers $\left(\mu \mathrm{g} / \mathrm{cm}^{2}\right)$

\begin{tabular}{lccc}
\hline Sample & BSA & BGG & FBG \\
\hline SPU-PDMS & $20.150 \pm 0.631$ & $13.222 \pm 1.589$ & $0.645 \pm 0.023$ \\
SPU-PDMS $_{\mathrm{HP}}-45$ & $25.052 \pm 0.096$ & $13.798 \pm 0.944$ & $0.711 \pm 0.011$ \\
SPU-PDMS $_{\mathrm{HP}-55}$ & $39.622 \pm 2.343$ & $16.460 \pm 1.336$ & $1.466 \pm 0.033$ \\
SPU-PDMS $_{\mathrm{EO}}-20$ & $17.050 \pm 0.953$ & $9.835 \pm 2.071$ & $0.157 \pm 0.009$ \\
SPU-PDMS $_{\mathrm{EO}}-45$ & $32.26 \pm 0.702$ & $10.688 \pm 0.734$ & $0.313 \pm 0.053$ \\
SPU-PDMS & & & \\
\hline
\end{tabular}

Our results indicate that SPU-PDMS copolymers have good surface properties, depending on the type of soft PDMS segments, which can be tailored for biomedical application requirements such as biomedical devices for short- and long-term uses. Copolymers based on EO-PDMS are less hydrophobic and have higher crystallinity (Table 1), as well as good microphase separation, which promoted better cell attachment and growth on polymer surface. EO-PDMS-based copolymers due to an excellent resistance to fibrinogen and stimulated endothelial cell adhesion properties

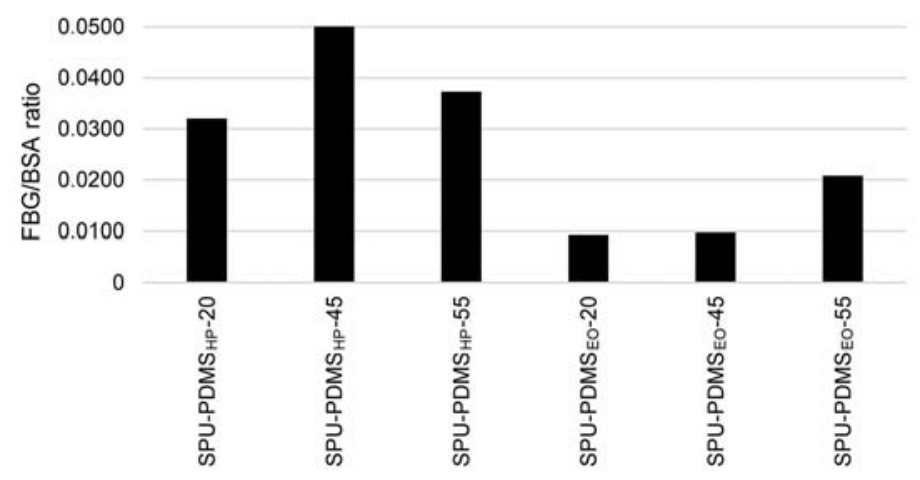

Figure 6. Fibrinogen/albumin ratio for SPU-PDMS copolymers from competitive adsorption experiments. 
might be found suitable for long-term biomedical application such as in cardiovascular devices that particularly require good blood compatibility and stimulated attachment of endothelial cells. However, the obtained results showed that HP-PDMS-based copolymers have good hemocompatibility due to the excellent resistance to fibrinogen adsorption, but show low endothelial cell adhesion. These results are consistent with previous studies [31] reporting that PDMS imparted a hydrophobic character to the surface of PDMS polyether polyurethanes that may have resulted in lower cell density and cell coverage, but enhanced biostability as compared to polyether polyurethanes. Our results on endothelial cell line prompt us to propose that HPPDMS-based copolymers might be found suitable for transient devices such as blood contacting portion of blood pumps and catheters. However, a further investigation (using different cell lines as well as blood-based tastings) is needed to clarify their potential for use in short-term biomedical devices.

\section{CONCLUSION}

The results of the current study show that the type of soft PDMS segments in the copolymers plays an important role in protein adsorption and endothelial cell adhesion onto the copolymer surfaces. The obtained results confirm good blood compatibility of synthesized copolymers since all copolymers exhibit good resistance to fibrinogen adsorption and all favor albumin adsorption. However, the higher surface energy and good microphase separation may partially account for a better hemocompatibility of copolymers based on EO-PDMS compared to HP-PDMS based copolymers. Our results imply that the surface of EO-PDMS based copolymers is more favourable for the cell attachment and growth than the surface of HPPDMS based copolymers, probably due to the greater hydrophilic properties of surfaces of these materials. Copolymers based on HP-PDMS significantly inhibit attachment and growth of EA.hy926 cells, as demonstrated through the decrease in viability of cells grown in the presence of these copolymer films, which could be a consequence of the restricted ability of cells to attach on their surface. Therefore, the synthesized SPUs based on HP-PDMS due to good hemocompatibilty and cells non-adherent properties should be further investigated as potential materials that might be used in biomedical devices for short-term use. Furthermore, our results show that SPUs based on the EO-PDMS soft segment favor the adhesion of endothelial cells on their surface as compared to HP-PDMS based SPUs, due to the presence of hydrophilic ethylene oxide terminal units in the soft segment, implying that these copolymers might be used in long-term biomedical application.

\section{Acknowledgements}

This work was financially supported by the Ministry of Education, Science and Technological Development of the Republic of Serbia (Project No. 172062).

\section{REFERENCES}

[1] R. Vermette, H.J. Griesser, G. Laroche, R. Guidoin, Biomedical Appliactions of Polyurethanes, Landes Bioscience, Austin, TX, 2001.

[2] S. Gogolewski, Selected topics in biomedical polyurethanes. A review, Colloid Polym. Sci. 267 (1989) 757$-785$.

[3] P.R. Dvornic, R.W. Lenz, High Temperature Siloxane Elastomers, Hüthing \& Wepf, Heidelberg and New York 1990.

[4] I. Yilgör, J. McGrath. Polysiloxane containing copolymers: A survey of recent developments. Polysiloxane Copolymers/Anionic Polymerization, Adv. Polym. Sci. 86 (1988) 1-86.

[5] D.K. Chattopadhyay, K.V.S.N. Raju, Structural engineering of polyurethane coatings for high performance applications, Prog. Polym. Sci. 32 (2007) 352-418.

[6] R.W. Hergenrother, Y. Xue-Hai, S.L. Cooper, Bloodcontacting properties of polydimethylsiloxane polyureaurethanes, Biomaterials 15 (1994) 635-640.

[7] J.P. Sheth, A. Aneja, G.L. Wilkes, E. Yilgor, G.E. Atilla, I. Yilgor, F.L. Beyer, Influence of system variables on the morphological and dynamic mechanical behavior of polydimethylsiloxane based segmented polyurethane and polyurea copolymers: a comparative perspective, Polymer 45 (2004) 6919-6932.

[8] P.A. Gunatillake, G.F. Meijs, S.J. Mccarthy, R. Adhikari, Poly(dimethylsiloxane)/poly(hexamethylene oxide) mixed macrodiol based polyurethane elastomers. I. Synthesis and properties, J. Appl. Polym. Sci. 76 (2000) 2026-2040.

[9] T. Choi, J. Weksler, A. Padsalgikar, J. Runt, Microstructural organization of polydimethylsiloxane soft segment polyurethanes derived from a single macrodiol, Polymer 51 (2010) 4375-4382.

[10] R. Hernandez, J. Weksler, A. Padsalgikar, T. Choi, E. Angelo, J.S. Lin, L.-C. Xu, C.A. Siedlecki, J. Runt, A Comparison of Phase Organization of Model Segmented Polyurethanes with Different Intersegment Compatibilities, Macromolecules 41 (2008) 9767-9776.

[11] R. Hernandez, J. Weksler, A. Padsalgikar, J. Runt, In vitro oxidation of high polydimethylsiloxane content biomedical polyurethanes: Correlation with the microstructure, J. Biomed. Mater. Res., A 87 (2008) 546-556.

[12] D.V. Bax, A. Kondyurin, A. Waterhouse, D.R. McKenzie, A.S. Weiss, M.M.M. Bilek, Surface plasma modification and tropoelastin coating of a polyurethane co-polymer for enhanced cell attachment and reduced thrombogenicity, Biomaterials 35 (2014) 6797-6809.

[13] M. Yaseen, X. Zhao, A. Freund, A.M. Seifalian, J.R. Lu, Surface structural conformations of fibrinogen polypeptides for improved biocompatibility, Biomaterials $\mathbf{3 1}$ (2010) 3781-3792. 
[14] M. Bil, J. Ryszkowska, P. Woźniak, K.J. Kurzydłowski, M. Lewandowska-Szumieł, Optimization of the structure of polyurethanes for bone tissue engineering applications, Acta Biomat. 6 (2010) 2501-2510.

[15] D. Spiller, C. Mirtelli, P. Losi, E. Briganti, S. Sbrana, C. Counoupas, S. Kull, S. Tonlorenzi, G. Soldani, In vitro evaluation of the PEtU-PDMS material immunocompatibility: the influence of surface topography and PDMS content, J. Mater. Sci. Mater. Med. 20 (2009) 2511-2520.

[16] M.V. Pergal, V.V. Antic, G. Tovilovic, J. Nestorov, D. Vasiljevic-Radovic, J. Djonlagic, In Vitro Biocompatibility Evaluation of Novel Urethane-Siloxane Co-Polymers Based on Poly( $\varepsilon$-Caprolactone)-block-Poly(Dimethylsiloxane)-block-Poly( $\varepsilon$-Caprolactone), J. Biomat. Sci., Polym. Edn. 23 (2012) 1629-1657.

[17] M.V. Pergal, J. Nestorov, G. Tovilovic, S. Ostojic, D. Gođevac, D. Vasiljevic-Radovic, J. Djonlagic, Structure and properties of thermoplastic polyurethanes based on poly(dimethylsiloxane): assessment of biocompatibility, J. Biomed. Mater. Res., A 102 (2014) 3951-3964.

[18] I.S. Stefanović, J. Djonlagić, G. Tovilović, J. Nestorov, V.V. Antić, S. Ostojić, M.V. Pergal, Poly(urethane-dimethylsiloxane) copolymers displaying a range of soft segment contents, noncytotoxic chemistry, and nonadherent properties toward endothelial cells, J. Biomed. Mater. Res., A (2014), DOI: 10.1002/jbm.a.35285.

[19] M.V. Pergal, i.S. Stefanovic, D. Gođevac, V.V. Antic, V. Milacic, S. Ostojic, J. Rogan, J. Djonlagic, Structural, thermal and surface characterization of thermoplastic polyurethanes based on poly(dimethylsiloxane), J. Serb. Chem. Soc. 79 (2014) 843-866.

[20] A. Marand, J. Dahlin, D. Karlsson, G. Skarping, M. Dalene, Determination of technical grade isocyanates used in the production of polyurethane plastics, J. Environ. Monit. 6 (2004) 606-614.

[21] C.J. Van Oss, R.J. Good, M.K. Chaudhury, Additive and nonadditive surface tension components and the interpretation of contact angles, Langmuir 4 (1988) 884-891.
[22] D.K. Owens, R.C. Wendt, Estimation of the surface free energy of polymers, J. Appl. Polym. Sci. 13 (1969) 1741-1747 .

[23] J. Vince, B. Orel, A. Vilčnik, M. Fir, A. Šurca Vuk, V. Jovanovski, B. Simončič, Structural and Water-Repellent Properties of a Urea/Poly(dimethylsiloxane) Sol-Gel Hybrid and Its Bonding to Cotton Fabric, Langmuir 22 (2006) 6489-6497.

[24] D.W. Van Krevelen, Properties of Polymers, Elsevier, Amsterdam, 1990.

[25] Ł. Byczyński, Effect of different polyethers on surface and thermal properties of poly(urethane-siloxane) copolymers modified with side-chain siloxane, J. Therm. Anal. Calorim. 114 (2013) 397-408.

[26] P. Majumdar, S. Stafslien, J. Daniels, D. Webster, High throughput combinatorial characterization of thermosetting siloxane-urethane coatings having spontaneously formed microtopographical surfaces, J. Coat. Technol. Res. 4 (2007) 131-138.

[27] S.P. Victor, C.P. Sharma, Development and evaluation of cyclodextrin complexed hydroxyapatite nanoparticles for preferential albumin adsorption, Colloids Surfaces, B 85 (2011) 221-228.

[28] S.-L. Huang, M.-S. Chao, R.-C. Ruaan, J.-Y. Lai, Microphase separated structure and protein adsorption of polyurethanes with butadiene soft segment, Eur. Polym. J. 36 (2000) 285-294.

[29] T.G. Grasel, S.L. Cooper, Surface properties and blood compatibility of polyurethaneureas, Biomaterials 7 (1986) 315-328.

[30] D. Cozzens, A. Luk, U. Ojha, M. Ruths, R. Faust, Surface Characterization and Protein Interactions of Segmented Polyisobutylene-Based Thermoplastic Polyurethanes, Langmuir 27 (2011) 14160-14168.

[31] A.B. Mathur, T.O. Collier, W.J. Kao, M. Wiggins, M.A. Schubert, A. Hiltner, J.M. Anderson, In vivo biocompatibility and biostability of modified polyurethanes, J. Biomed. Mater. Res., A 36 (1997) 246-257. 


\section{IZVOD}

\section{POVRŠINSKA KARAKTERIZACIJA, HEMO- I CITOKOMPATIBILNOST SEGMENTIRANIH POLIURETANA NA BAZI POLI(DIMETILSILOKSANA)}

Marija V. Pergal ${ }^{1}$, Jelena Nestorov ${ }^{2}$, Gordana Tovilović-Kovačević ${ }^{2}$, Petar Jovančić ${ }^{3}$, Lato Pezo ${ }^{4}$, Dana Vasiljević-Radović ${ }^{1}$, Jasna Djonlagić ${ }^{3}$

${ }^{1}$ Institut za hemiju, tehnologiju i metalurgiju, Univerzitet u Beogradu, Beograd, Srbija

${ }^{2}$ Odeljenje za biohemiju, Institut za biološka istraživanja "Siniša Stanković", Univerzitet u Beogradu, Beograd, Srbija

${ }^{3}$ Fakultet za tehnologiju i metalurgiju, Univerzitet u Beogradu, Beograd, Srbija

${ }^{4}$ Institut za opštu i fizičku hemiju, Univerzitet u Beogradu, Beograd, Srbija

\section{(Naučni rad)}

Segmentirani poliuretani na bazi poli(dimetilsiloksana), koji se trenutno koriste $u$ biomedicini, imaju biokompatibilnost ispod optimalne što smanjuje njihovu efikasnost. Poboljšavajući vezivanje endotelnih ćelija i svojstva kopolimera na bazi PDMS u dodiru sa krvlju značajno bi se poboljšala i proširila njihova klinička primena. $U$ ovom radu su proučavana površinska svojstva $\mathrm{i}$ in vitro biokompatibilnost dve serije segmentiranih poli(uretan-dimetilsiloksana) (SPU-PDMS) na bazi hidroksipropil- $\mathrm{i}$ hidroksietoksipropil- PDMS pretpolimera sa potencijalnim primenama u medicinskim uredjajima u kontaktu sa krvlju. SPU-PDMS kopolimeri su karakterisani merenjem kontaktnih uglova, određivanjem površinske energije (izračunate prema van Oss-Chaudhury-Good i Owens-Wendt metodama), i mikroskopijom atomskih sila. Biokompatibilnost kopolimera je ispitivana primenom endotelnih EA.hy926 ćelija u direktnom kontaktu, pre i nakon pretretiranja kopolimera sa višekomponentnom smešom proteina, kao i pomoću kompetitivne adsorpcije proteina. Dobijeni rezultati su potvrdili da sintetisani kopolimeri imaju dobru kompatibilnost prema krvi. Svi sintetisani kopolimeri pokazivali su dobru otpornost prema adsorpciji fibrinogena i svi kopolimeri su favorizovali adsorpciju albumina. Kopolimeri na bazi hidroksietoksipropil-PDMS imali su manju hidrofobnost, veću površinsku energiju, i bolju mikrofaznu separaciju u poređenju sa kopolimerima na bazi hidroksipropil-PDMS, što je dovelo do boljeg vezivanja i rasta endotelnih ćelija na površini ovih polimera u poređenju sa kopolimerima na bazi hidroksipropil-PDMS. Rezultati su pokazali da SPU-PDMS kopolimeri prikazuju dobra površinska svojstva, zavisno od vrste mekih PDMS segmenata, koja se mogu prilagođavati zahtevima u biomedicini, kao što su biomedicinski uređaji za kratkoročnu i dugoročnu upotrebu.
Ključne reči: Poliuretani - Siloksani • Površinska energija • Vezivanje ćelija • Adsorpcija proteina 